\title{
Reduced concentrations of HIV-RNA and TNF- $\alpha$ coexist in CSF of AIDS patients with progressive multifocal leukoencephalopathy
}

\author{
Laura Monno, Giovanni B Zimatore, Mariantonietta Di Stefano, Amelia Appice, \\ Paolo Livrea, Gioacchino Angarano
}

\begin{abstract}
Objectives-To confirm reduced human immunodeficiency virus type-1 (HIV-1) burden in the CSF of patients with progressive multifocal leukoencephalopathy (PML) and to verify whether this viral load coincides with the absence of inflammatory changes in the CSF.

Methods-Paired CSF and plasma samples from 17 patients with PML, 26 with non-PML cerebral opportunistic infections, nine with HIV-1 leukoencephalopathy (HIVE), and 12 neurologically asymptomatic AIDS patients were subjected to HIV-RNA titration. Tumour necrosis factor (TNF)- $\alpha$ was also measured and the CSF albumin: serum albumin ratio $\left(Q_{\mathrm{Alb}}\right)$ was calculated.

Results-The CSF HIV-1 burden of patients with PML did not differ from that of neurologically asymptomatic patients $(p=0.21)$, but was significantly lower than CSF burden of the remaining patients (non-PML opportunistic infections, $p<0.001$; HIVE, $p<0.001) . Q_{\mathrm{Alb}}$ was normal for all neurologically asymptomatic patients, for $86.6 \%$ patients with PML, and $62.5 \%$ patients with HIVE $(p=0.09) . Q_{\text {Alb }}$ was altered in $91.6 \%$ patients with nonPML opportunistic infections. TNF- $\alpha$ in CSF was higher in patients with non-PML opportunistic infections $(p<0.001)$ and those with HIVE $(p<0.001)$ than in patients with PML who consistently had TNF $-\alpha$ concentrations $<10 \mathrm{pg} / \mathrm{ml}$.

Conclusions-These results, while indicating a reduced HIV replication in CSF of patients with PML which might serve as a disease marker, emphasise the increased CSF HIV-RNA concentration in patients with HIVE and patients with non-PML opportunistic infections. Low concentrations of HIV-RNA in CSF coincide with reduced TNF- $\alpha$ concentrations, possibly due to particular features of PML compared with other opportunistic infections as it develops without detectable inflammatory changes in the CSF.

(F Neurol Neurosurg Psychiatry 1999;67:369-373)
\end{abstract}

Keywords: progressive multifocal leukoencephalopathy; cerebrospinal fluid, HIV-RNA titration; TNF- $\alpha$; CSF albumin:serum albumin ratio

Human immunodeficiency virus type 1 (HIV-1) burden in the peripheral blood has recently been recommended as a powerful and independent prognostic indicator of $\mathrm{HIV}-1$ disease progression. ${ }^{1}$ However, a transient increase in plasma HIV-RNA can be measured during the course of an active opportunistic infection superimposed on HIV-1 disease ${ }^{2}$; therefore, particular caution is required in interpreting the results of viral load.

Increased HIV-RNA concentrations in CSF have been associated with HIV-1 leukoencephalopathy (HIVE). ${ }^{3}{ }^{4}$ However, Brew et al also found increased CSF HIV-RNA concentrations in patients with neurological diseases other than HIVE, ${ }^{5}$ and they suggested that a rising CSF viral load could be the consequence of recruitment of HIV-1 infected inflammatory cells.

This finding casts a new light on the hypothesis of Price and Staprans who postulated that two distinct types of HIV-1 infection could be detected in CSF. ${ }^{6}$ A transitory traffic of virus infected cells from the blood into the CSF might cause brain infection during the early phase of HIV-1 disease, and an autonomous self sustaining infection would mirror CNS disorders strictly related to HIV-1. On the basis of the above findings, we can hypothesise that a transitory infection regularly coincides with any opportunistic infection of the CNS causing the importation of fresh infected cells from the peripheral compartment and also the increased number of activated CD4+ cells sustaining the productive HIV-1 infection. $^{5}$

Previously, we confirmed that increased concentrations of HIV-RNA may be detected in the CSF of patients with opportunistic infections localised in the CNS. ${ }^{37}$ However, even if limited to a few patients, progressive multifocal leukoencephalopathy (PML) seemed to present an exception to this rule. ${ }^{7}$

Herein we confirm the presence of reduced CSF HIV-RNA concentrations in a larger group of HIV positive patients with PML and discuss the possibility that this finding might be a consequence of the particular features of PML with respect to other opportunistic infections in that it seems to develop without detectable inflammatory changes in $\mathrm{CSF}^{8}$ To support this latter hypothesis, we also compared the degree of blood-brain barrier impairment and the levels of tumour necrosis factor (TNF) $-\alpha$ in the CSF of patients with PML with those of patients both neurologically asymptomatic and with opportunistic infections of CNS other than PML or with HIVE. and in revised form

7 April 1999

Accepted 13 April 1999 


\section{Patients and methods}

The study included $17 \mathrm{HIV}$ infected patients with PML diagnosed between 1986 and 1998, 26 patients with opportunistic infections of the CNS other than PML, nine with HIVE, and 12 neurologically asymptomatic AIDS patients. Paired CSF and plasma samples from these 64 patients were subjected to HIV-RNA titration. TNF- $\alpha$ was also measured and the CSF albumin:serum albumin ratio (Qalb) was calculated for the evaluation of impairment of the blood-brain barrier.

Diagnosis of PML was based on suggestive neurological symptoms and signs along with compatible white matter lesions of CNS on MRI evaluation. ${ }^{9}$ In all patients with PML, diagnosis was confirmed by testing CSF for the presence of JC virus (JCV)-DNA with the use of a nested polymerase chain reaction (PCR) protocol. ${ }^{10} \mathrm{~A}$ further confirmation of PML diagnosis was derived from necropsy in two patients.

HIV-RNA was quantified with a commercial RT-PCR (detection limit=200 copies $/ \mathrm{ml})(\mathrm{Am}$ plicor HIV-1 monitor test, Roche Molecular Systems). All samples were thawed only once. The $\mathrm{Q}_{\mathrm{Alb}}$ was calculated according to the formula:

$$
\mathrm{Q}_{\mathrm{Alb}}=\frac{\text { albumin conc in } \mathrm{CSF}(\mathrm{mg} / \mathrm{l}) \times 1000}{\text { albumin conc in serum }(\mathrm{g} / \mathrm{l})}
$$

Values of $Q_{\text {Alb }} \geqslant 8$ signified an altered blood brain barrier. ${ }^{11}$

An additional amount of never thawed CSF and 52 paired plasma samples were available for measurement of TNF- $\alpha$ with the commercial Medgenix (Fleurus, Belgium) enzyme amplified sensitivity immunoassay (EASIA). The detection limit of the assay was $3 \mathrm{pg} / \mathrm{ml}$, and according to the manufacturers' guidance, a mean value of $6 \pm 4 \mathrm{pg} / \mathrm{ml}$ was regarded as normal. For the purpose of analysis, the maximum normal value of $10 \mathrm{pg} / \mathrm{ml}$ of TNF- $\alpha$ was used.

The results of viral load, TNF- $\alpha$ titration, and $\mathrm{Q}_{\mathrm{Alb}}$ from the patient groups were analysed with the Kruskal-Wallis $H$ test and the MannWhitney test. Numbers of patients with impairment of the blood-brain barrier and detectable TNF- $\alpha$ were compared by the MantelHaenszel test and the Fisher's exact test.

\section{Results}

PATIENT CHARACTERISTICS

Patients with PML (13 men and four women, median age $=31$ years) had severe immunodeficiency (median CD4+ cell count $=57 \times$ $10^{6} / 1$, range $\left.7-110 \times 10^{6} / 1\right)$. For 13 patients, PML represented the first AIDS defining condition. At the time of PML diagnosis and CSF collection one patient was regularly receiving zidovudine and an additional patient was on treatment with zidovudine plus lamivudine. Eleven patients had not taken antiretroviral drugs and for the remaining four patients, antiretroviral drugs had been discontinued for at least 2 months before CSF sampling because of intolerance, non-compliance, or concomitant incompatible medications.
All patients had recently developed personality change, memory loss, cognitive and speech changes, motor and sensory abnormalities, and visual disturbance. In 16 patients MRI demonstrated typical white matter lesions. ${ }^{9}$ In one of these, a faint peripheral enhancement of the lesions was seen. The remaining patient had a single lesion which was hyperintense on T2 weighted images and isointense on $\mathrm{T} 1$ weighted images. Examination of CSF showed a normal cell count in all cases $($ cells $<5 / \mu 1)$ and an unaltered blood-brain barrier in 13 of 15 patients tested. Finally, CSF samples were negative for bacteria, fungi, protozoa, cytomegalovirus (CMV), and herpes simplex virus (HSV)-1 and HSV-2. Survival after diagnosis of PML was $<5$ months for all patients. Necropsy evaluation of two patients showed no additional concurrent opportunistic infection of the CNS.

The 12 neurologically asymptomatic patients who were admitted to hospital for AIDS related manifestations in sites other than the CNS had a median CD 4 count of $35 \times 10^{6} / 1$ cells (range $5-150 \times 10^{6} / 1$ ) and none had been taking antiretroviral drugs.

At the time of sampling, five of nine patients diagnosed as having HIVE according to the American Academy of Neurology criteria were receiving antiretroviral therapy. In patients with HIVE, median CD 4 count was $36 \times 10^{6} / 1$ cells, range $3-158 \times 10^{6} / 1$ cells.

The 26 patients with opportunistic infections of the CNS other than PML included 11 patients with cerebral toxoplasmosis, five with cryptococcal meningitis, three with cerebral tuberculosis, and seven with CMV leukoencephalopathy. In all these patients diagnosis was either established by culture or based on accepted criteria. ${ }^{12}$ For the purpose of analysis these 26 patients constituted a single group. All these patients were heavily immunosuppressed (median CD4 count $=20 \times 10^{6} / 1$, range $\left.4-150 \times 10^{6} / 1\right)$, nine of whom had a previous AIDS diagnosis. At the time of CSF sampling, a total of nine of 26 patients were on antiretroviral therapy.

TITRATION OF HIV-RNA

Median plasma log HIV-RNA concentrations were similar in the four patient groups $(p=0.08)$. Overall, HIV-RNA was detectable in all CSF samples. Concentrations of HIV-RNA in paired CSF and plasma samples of the 17 patients with PML are listed in table 1. Values for HIV-RNA in CSF were regularly lower than those in plasma; the median CSF value was $3.63 \log _{10}$ with 10 patients $(58.8 \%)$ having $<4$ $\log _{10}$ copies/ml CSF HIV-RNA. Moreover, some untreated patients had lower concentrations of CSF HIV-RNA than the two patients on antiretroviral therapy. Interestingly, the highest concentrations of CSF HIV-RNA detected in two patients coincided with impairment of the blood-brain barrier $\left(\mathrm{Q}_{\mathrm{Alb}}>8\right.$, table $1)$.

Concentrations of HIV-RNA in CSF differed in the 64 patients grouped according to neurological diagnosis. Whereas the median value of viral load in CSF of neurologically 
Table 1 Concentrations of HIV-RNA in paired CSF and plasma samples from 17 AIDS patients with progressive multifocal leukoencephalopathy (PML). $Q_{A l b}$ is also shown for each patient

\begin{tabular}{|c|c|c|c|c|c|c|}
\hline \multirow[b]{2}{*}{ Patient } & \multirow[b]{2}{*}{ 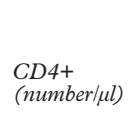 } & \multirow[b]{2}{*}{$Q_{A l b}$} & \multicolumn{3}{|c|}{$H I V-R N A\left(\log _{10}\right)$} & \multirow[b]{2}{*}{$\begin{array}{l}\text { Antiretroviral } \\
\text { drugs }\end{array}$} \\
\hline & & & $C S F$ & Plasma & $\begin{array}{l}\text { CSF/plasma } \\
\text { ratio }\end{array}$ & \\
\hline 1 & 92 & NA & 4.92 & 5.80 & 0.84 & Refused \\
\hline 2 & 97 & 4.34 & 4.37 & 5.33 & 0.81 & Naive \\
\hline 3 & 40 & 6.8 & 3.40 & 4.92 & 0.69 & Naive \\
\hline 4 & 36 & 16.63 & 5.95 & 6.13 & 0.97 & Naive \\
\hline 5 & 49 & 4.8 & 3.04 & 5.54 & 0.54 & Naive \\
\hline 6 & 88 & 3 & 2.69 & 4.70 & 0.57 & Refused \\
\hline 7 & 106 & 3.5 & 3.43 & 5.37 & 0.63 & $\mathrm{AZT}$ \\
\hline 8 & 27 & 5.99 & 3.48 & 5.88 & 0.59 & $\mathrm{AZT}+3 \mathrm{TC}$ \\
\hline 9 & 21 & 7 & 4.18 & 5.63 & 0.74 & Refused \\
\hline 10 & 7 & 7.67 & 4.72 & 5.72 & 0.82 & Naive \\
\hline 11 & 66 & 6.8 & 3.29 & 5.21 & 0.63 & Discontinued \\
\hline 12 & 102 & 10.18 & 5.48 & 6.09 & 0.89 & Discontinued \\
\hline 13 & 34 & 4.44 & 4.32 & 5.25 & 0.82 & Naive \\
\hline 14 & 98 & 3.1 & 3.95 & 5.05 & 0.78 & Discontinued \\
\hline 15 & 110 & 5.1 & 2.76 & 4.82 & 0.57 & Refused \\
\hline 16 & 8 & 3.93 & 3.51 & 4.82 & 0.72 & Discontinued \\
\hline 17 & 50 & NA & 3.63 & 4.63 & 0.78 & Naive \\
\hline
\end{tabular}

$\mathrm{Q}_{\text {Alb }}=$ albumin concentration in $\mathrm{CSF}(\mathrm{mg} / \mathrm{l}) \times 1000 /$ albumin concentration in serum $(\mathrm{g} / \mathrm{l}) ; \mathrm{NA}=$ not available; $\mathrm{AZT}=$ zidovudine; $3 \mathrm{TC}=$ lamivudine .

$\mathrm{CSF}$ cell count was always normal $(\leqslant 5$ cells $/ \mu \mathrm{l}) ; \mathrm{Q}_{\mathrm{Alb}} \geqslant 8$ signified an impaired blood-brain barrier.

asymptomatic patients $\left(3.48 \log _{10}\right)$ was similar to the CSF value of patients with PML $(\mathrm{p}=0.21)$, in patients with non-PML CNS opportunistic infections, CSF HIV-RNA concentration was much higher (median value, $5.32 \log _{10}$ copies/ml, $\left.\mathrm{p}<0.001\right)$. As expected, patients with HIVE had the highest CSF HIVRNA concentration (median value, $6.58 \log _{10}$; $\mathrm{p}<0.001$ ). Lastly, when the number of patients with CSF viral load above an arbitrary cut off value of $5 \log _{10}$ was calculated, only two of 17 $(11.7 \%)$ patients with PML but 15 of 26 (57.6\%) of those with CNS non-PML opportunistic infections and nine of nine (100\%) patients with HIVE had a CSF HIV-1 burden exceeding this concentration $(p<0.001)$. This result was obtained even if patients neurologically asymptomatic were grouped together with those with CNS abnormalities other than PML $(p=0.005)$.

CSF ALBUMIN: SERUM ALBUMIN RATIO

For 56 of 64 patients, the $\mathrm{Q}_{\mathrm{Alb}}$ was calculated and an impaired blood-brain barrier $\left(\mathrm{Q}_{\mathrm{Alb}}>8\right)$ was diagnosed in $27(48 \%)$. The results are detailed in table 2. $\mathrm{Q}_{\mathrm{Alb}}$ was normal among neurologically asymptomatic patients, also in 13 of $15(86.6 \%)$ patients with PML and in five of eight $(62.5 \%)$ patients with HIVE $(p=0.09)$. By contrast, 22 of $24 \quad(91.6 \%)$ patients with opportunistic infections other than PML had $\mathrm{Q}_{\mathrm{Alb}}$ values exceeding the normal. The median $\mathrm{Q}_{\text {Alb }}$ value in patients with PML was similar to the median values obtained from neurologically asymptomatic patients $(p=0.12)$ and those with HIVE $(p=0.07)$. Conversely, $Q_{\text {Alb }}$ in patients with non-PML opportunistic infections (median value $=13.7$; range $4.0-43.7$ ) was significantly higher than the value obtained in patients with PML $(\mathrm{p}<0.001)$.

MEASUREMENT OF TUMOUR NECROSIS FACTOR- $\alpha$ $(\mathrm{TNF}-\alpha)$

In all plasma samples, $\mathrm{TNF}-\alpha$ concentration was $>10 \mathrm{pg} / \mathrm{ml}$ irrespective of neurological diagnosis $(p=0.24$, table 2$)$.

Concentrations of TNF- $\alpha$ in CSF above the assay sensitivity limit were detected in 55 of 64 (85.9\%) patients studied. TNF- $\alpha$ was undetectable in the CSF of four neurologically asymptomatic patients, four patients with PML, and in an additional patient with cerebral toxoplasmosis. Details of TNF- $\alpha$ measurement in CSF are shown in table 2. The TNF- $\alpha$ concentration in the CSF of patients with PML was similar to that in asymptomatic patients $(p=0.32)$ as was also the number of patients with TNF- $\alpha$ concentrations $>10 \mathrm{pg} / \mathrm{ml}$ in the two groups $(\mathrm{p}=0.61)$. TNF- $\alpha$ was significantly higher in patients with HIVE and those with non-PML opportunistic infections than in those with PML $(\mathrm{p}<0.001$ and $\mathrm{p}<0.001$, respectively). Moreover, all patients with HIVE and 19 (76\%) with non-PML opportunistic infections had concentrations of CSF TNF- $\alpha$ concentrations $>10$ $\mathrm{pg} / \mathrm{ml}$ (HIVE $v$ PML, $\mathrm{p}=0.02$; non-PML opportunistic infections $v$ PML, $\mathrm{p}<0.001$, respectively).

Finally, TNF- $\alpha$ concentrations that were by far higher in CSF than in plasma were found in two patients with non-PML opportunistic infections.

Table 2 Blood-brain barrier evaluation and measurement of plasma and CSF TNF-a in patients divided by neurological diagnosis

\begin{tabular}{|c|c|c|c|c|}
\hline Neurological diagnosis & Asymptomatic & $P M L$ & HIVE & OIs non-PML \\
\hline \multicolumn{5}{|l|}{$\mathrm{Q}_{\mathrm{Alb}}:$} \\
\hline Patients tested & 9 & 15 & 8 & 24 \\
\hline Median value (range) & $4.0(2.9-6.7)$ & $5.1(3.0-16.6)$ & $6.9(5.8-14)$ & $13.7(4.0-43.7)$ \\
\hline Patients with $\mathrm{Q}_{\mathrm{alb}}>8$ & 0 & $2(13.3 \%)$ & $3(37.5 \%)$ & $22(91.6 \%)$ \\
\hline \multicolumn{5}{|l|}{ CSF TNF- $\alpha$ : } \\
\hline Patients with detectable TNF- $\alpha$ & $8 / 12$ & $13 / 17$ & $9 / 9$ & $25 / 26$ \\
\hline Median value (range) & $4.2(3.2-6.7)$ & $6.0(3.2-10.5)$ & $11.3(7.0-16.0)$ & $17.8(3.5-532)$ \\
\hline Patients with TNF- $\alpha>10$ & 0 & $1(7.6 \%)$ & $5(55.5 \%)$ & $19(76 \%)$ \\
\hline \multicolumn{5}{|l|}{ Plasma TNF- $\alpha$ : } \\
\hline Patients tested & 11 & 11 & 8 & 22 \\
\hline Median value (range) & $36(12.8-88)$ & $22(13.7-146)$ & $50.1(10.4-127.4)$ & $38.3(23.0-127)$ \\
\hline Patients with TNF- $\alpha>10$ & $11(100 \%)$ & $11(100 \%)$ & $8(100 \%)$ & $22(100 \%)$ \\
\hline
\end{tabular}

$\mathrm{PML}=$ progressive multifocal leukoencephalopathy; HIVE=HIV-1 leukoencephalopathy; OIs=opportunistic infections). $\mathrm{Q}_{\mathrm{Alb}} \geqslant 8$ signified an impaired blood-brain barrier. TNF- $\alpha$ values are expressed as $\mathrm{pg} / \mathrm{ml}$. Values of TNF- $\alpha$ up to $10 \mathrm{pg} / \mathrm{ml}$ were regarded as normal.

Statistical analysis. $\mathrm{Q}_{\mathrm{Alb}}$ value: asymptomatic $v$ PML, $\mathrm{p}=0.12$; HIVE $v$ PML, $\mathrm{p}=0.07$; OIs non-PML $v$ PMl, $\mathrm{p}<0.001$.

Patients with $\mathrm{Q}_{\mathrm{Al}} \geqslant 8$ : asymptomatic $v$ PML, $\mathrm{p}=0.38$; HIVE $v$ PML, $\mathrm{p}=0.20$; OIs non-PML $v$ PMl, $\mathrm{p}<0.001$

CSF TNF- $\alpha$ concentrations: asymptomatic $v$ PML, $\mathrm{p}=0.32$; HIVE $v$ PML, $\mathrm{p}<0.001$; OIs non-PML $v$ PMl, $\mathrm{p}<0.001$.

Patients with TNF- $\alpha>10$ pg/ml: asymptomatic $v$ PML, $\mathrm{p}=0.61$; HIVE $v$ PML, $\mathrm{p}=0.02$; OIs non-PML $v$ PMl, $\mathrm{p}<0.001$. 
CORRELATION BETWEEN $Q_{\text {ALB }}$ AND TNF- $\alpha$ AND CSF VIRAL LOAD

To evaluate a possible correlation between blood-brain barrier damage and $\mathrm{TNF}-\alpha$ with CSF HIV-1 burden, patients were divided in two groups according to an arbitrary threshold value of CSF HIV-RNA of $5 \log _{10}$. Overall, 25 and 31 patients had CSF HIV-RNA concentrations above and below $5 \log _{10} / \mathrm{ml}$, respectively. $\mathrm{Q}_{\mathrm{Alb}}$ was significantly related to CSF HIV-RNA concentration $(p<0.001)$ as was the median concentration of CSF TNF- $\alpha \quad(p<0.001)$. Moreover, significant relations were found between CSF HIV-RNA and the number of subjects with blood-brain barrier damage $(\mathrm{p}<0.001)$ and concentrations of $\mathrm{TNF}-\alpha$ in $\mathrm{CSF}>10 \mathrm{pg} / \mathrm{ml}(\mathrm{p}=0.002)$.

\section{Discussion}

In a previous study we measured unexpectedly low concentrations of HIV-RNA in the CSF of patients with PML. ${ }^{7}$ A similar result was reported by Brew et al, who found that patients with PML had a CSF viral load between 200 and 503 copies $/ \mathrm{ml}^{5}$

In the present study, we confirm that low values of HIV-RNA are almost always detected in CSF of patients with PML as in neurologically asymptomatic patients $(p=0.21)$; by contrast, a statistically significant difference does exist with respect to CSF HIV-RNA concentrations in patients with HIVE $(\mathrm{p}<0.001)$ but also in those with opportunistic infections of the CNS other than PML $(p<0.001)$.

The particular features of JCV infection compared with other opportunistic infections might provide some explanations for these results.

The causal agent of PML is JCV, ${ }^{13}$ the incidence of which has increased with the AIDS epidemic. ${ }^{14}{ }^{15}$ Two possible explanations can be offered for this correlation. The first is represented by the possibility of a direct interaction between HIV-1 and JCV, ${ }^{16}{ }^{17}$ but in vivo, the mutual transactivation of JCV and HIV-1 in the same cell has been excluded. ${ }^{18}$ Secondly, as PML can also be found in other conditions associated with a defect of cell mediated immunity, the increased frequency of PML in AIDS patients may simply reflect the severe immunodeficiency associated with AIDS.

Antibodies to JCV are commonly detected in the normal population without clinical manifestations. ${ }^{19}$ In these patients, JCV remains in a latent state in the kidneys, the stem cells of bone marrow and B lymphocytes until the host becomes immunosuppressed ${ }^{20}$; at this time viral reactivation can occur. ${ }^{21}$ The JCV then moves to the CNS through B lymphocytes ${ }^{20}$ and scatters into the brain where the virus seeks the oligodendrocytes which provide the transcription factors for JCV expression. ${ }^{15}{ }^{20}$ In the brain, JCV determines the destruction of oligodendrocytes and the development of a demyelinating disease. Inflammatory infiltrates are rare ${ }^{15}$ thus explaining the term leukoencephalopathy rather than leukoencephalitis, and are limited to a few patients in whom residual immunocompetence permits the viral clearance and prolongs survival. $^{22} 23$ Lipid laden macrophages in the demyelinating lesions function as "sweepers" by removing the myelin breakdown products, but they do not necessarily transport HIV-1 into the brain. ${ }^{24}$ In this situation, we can presume that the complex network of proinflammatory cytokines remains relatively unaltered.

Vullo et al found that the concentrations of soluble receptors for TNF- $\alpha$ (sTNFr) in CSF of patients with PML did not differ from those of neurologically asymptomatic HIV positive patients and HIV negative controls. ${ }^{8}$ Conversely, high sTNFr concentrations were detected in the CSF of patients with non-PML opportunistic infections, thus indicating that the production of sTNFr can be reduced in PML patients. If so, in patients with PML it would seem that the cellular immune system is not stimulated to produce cytokines such as TNF- $\alpha$ and IFN $\gamma$, which in turn induce HIV-1 replication. ${ }^{25}$ Our data regarding the concentrations of TNF- $\alpha$ in the CSF of patients with PML support this hypothesis, thus explaining the low concentrations of HIV-1 replication in the CSF of these patients.

However, in our study high HIV-RNA concentrations were also measured in the CSF of two patients who had an impaired bloodbrain barrier. As in other series, ${ }^{2426}{ }^{27}$ the possibility that PML is combined with alterations caused by an additional agent cannot be excluded, thereby suggesting that inflammation could represent the response to a pathogen in addition to JCV. The most plausible concurrent agent is HIV-1 itself. HIV-1 normally infects the $\mathrm{CNS},{ }^{28}$ but an important factor leading to the cerebral damage is the stimulation of HIV induced cytokine production with a possible blood-brain barrier change (as in our two patients). ${ }^{29}$ This is a reasonable explanation for some studies reporting inflammatory perivascular infiltrates in the brain of AIDS patients with PML. ${ }^{263031}$ In these papers, which are often limited to a few patients, PML with inflammatory alterations are actually referred to as "atypical" PML and an "unambiguous JCV directed inflammation" was not definitively proved. ${ }^{26} 31$

Finally, whereas it has been suggested that the presence of inflammatory PML lesions seems to herald a better prognosis for the disease in these patients, ${ }^{30}$ we cannot ignore the fact that this result seems to be achieved when the blood-brain barrier remains unaltered. In our series, patients with raised $\mathrm{Q}_{\mathrm{Alb}}$ died shortly after the diagnosis, thus indicating that particular caution regarding prognosis should be used in the presence of inflammatory changes which accompany PML. ${ }^{27}$

In conclusion, our data confirm a reduced HIV replication in the CSF of patients with PML, and further emphasises the increased CSF viral load in patients with HIVE and nonPML opportunistic infections. The regularly low concentrations of HIV-RNA in the CSF of patients with PML indicate that CSF HIV-1 titration could be included in the algorithm for PML diagnosis. Actually, our data are not surprising because, unlike other infections of the 
CNS in HIV positive patients, PML seems to develop without inflammatory changes such as an increased TNF- $\alpha$ concentration. Hopefully, these findings will stimulate further investigations into the pathogenetic mechanisms in PML.

We are grateful to Antonio Spinelli and Antonella Lagioia for technical assistance and to Paulene Butts for her help in the preparation of the manuscript. This work was supported in part by Istituto Superiore di Sanità, Rome, Contract Nos 30A.0.42 and 40A.0.05.

1 Mellors J, Munoz A, Giorgi J, et al. Plasma viral load and CD4+ lymphocytes as prognostic markers of HIV-1 infection. Ann Intern Med 1997;126:946-54.

2 Donovan RM, Bush CE, Markowitz NP, et al. Changes in virus load markers during AIDS-associated opportunistic diseases in human immunodeficiency virus infected persons. F Infect Dis 1996;174:401-3.

3 Di Stefano M, Monno L, Fiore JR, et al. In vivo evidence of HIV-1 productive infection in cerebrospinal fluid of patients with HIV-1 encephalitis. AIDS 1997;11:133-5.

4 Di Stefano M, Monno L, Fiore JR, et al. Neurological disorders during HIV-1 infection correlate with viral load in cerebrospinal fluid but not with virus phenotype. AIDS 1998 ; 12:737-43.

5 Brew B, Pemberton L, Cunningham P, et al. Levels of human immunodeficiency virus type 1 RNA in cerebrospinal fluid correlate with AIDS dementia stage. F Infect Di 1997;175:963-6.

6 Price RW, Staprans S. Measuring the viral load in cerebrospinal fluid in human immunodeficiency virus infection: window into brain infection? Ann Neurol 1997;42:675-8.

7 Monno L, Di Stefano M, Zimatore GB, et al. Measuremen of viral sequences in cerebrospinal fluid of AIDS patients with cerebral white-matter lesions using polymerase chain reaction. AIDS 1998;12:581-90

8 Vullo V, Mastroianni CM, Lichtner M, et al. Increased cerebrospinal fluid levels of soluble receptors for tumor necrosis factor in HIV-infected patients with neurological diseases. AIDS 1995;9:1099-112.

9 Whiteman MLH, Post MJD, Berger JR, et al. Progressive multifocal leukoencephalopathy in 47 HIV-seropositive patients: neuroimaging with clinical and pathologic correpatients: neuroimaging with clinical

10 Cinque P, Vago L, Dahl H, et al. Polymerase chain reaction on cerebrospinal fluid for diagnosis of virus-associated opportunistic diseases of the central nervo
HIV-infected patients. AIDS 1996;10:951-8.

11 Andersson M, Alvarez Cermeno J, Bernardi G, et al. Cerebrospinal fluid in the diagnosis of multiple sclerosis: a consensus report. F Neurol Neurosurg Psychiatry 1994;57: 897-902.

12 Simpson DM, Tagliati M. Neurological manifestations of HIV infection. Ann Intern Med 1994;121:769-85.

13 Padgett BL, Walker DL, Zu Rhein GM, et al. Cultivation of papova-like virus from human brain with progressive
multifocal leukoencephalopathy. Lancet 1971;i:1257-60.

14 Berger JR Kaszovitz, Donovan Post MJ, et al. Progressive multifocal leukoencephalopathy associated with human immunodeficiency virus infection. A review of the literature with report of 16 cases. Ann Intern Med 1987;107:78-87.
15 Major EO, Amemiya K, Tornatore CS, et al. Pathogenesis and molecular biology of progressive multifocal leukoencephalopathy, the JC virus-induced demyelinating disease of the human brain. Clin Microbiol Rev 1992;5:49-73.

16 Gendelman HE, Phelps W, Feigenbaum L, et al. Transactivation of the human immunodeficiency virus long terminal repeat sequence by DNA viruses. Proc Natl Acad Sci USA 1986;83:9759.

17 Tada H, Rappaport J, Lashgari M, et al. Trans-activation of the JC virus late promoter by the tat protein of type 1 human immunodeficiency virus in glial cells. Proc Natl Acad Sci USA 1990;87:3479-83.

18 Vazeux R, Cumont M, Girard PM, et al. Severe encephalitis resulting from coinfections with HIV and JC virus. Neuroloy 1990;40:944-8.

19 Walker DL, Padgett BL. The epidemiology of human polyomaviruses. In: Sever JL, Madden D, eds. Polyomaviruses and Human Neurological Diseases. New York: Alan R Liss, 1983:99-106.

20 Houff SA, Major EO, Katz D, et al. Involvement of JC virusinfected mononuclear cells from the bone marrow and spleen in the pathogenesis of progressive multifocal leukoencephalopathy. $\mathrm{N} \mathrm{Engl} \mathrm{F} \mathrm{Med} \mathrm{1988;318:301-5.}$

21 Richardson EP Jr. Our evolving understanding of progressive multifocal leukoencephalopathy. Ann NY Acad Sci 1974;230:358-64.

22 Major EO, Ault GS. Progressive multifocal leukoencephalopathy: clinical and laboratory observations on a viral induced demyelinating disease in the immunodeficient patient. Curr Opin Neurol 1995;8:184-90.

23 Berger JR, Mucke L. Prolonged survival and partial recovery in AIDS-associated progressive multifocal leukoencephalopathy. Neurology 1988;38:1060-5.

24 Rhodes RH, Ward JM, Walker DL, et al. Progressive multifocal leukoencephalopathy and retroviral encephalitis in acquired immunodeficiency syndrome. Arch Pathol Lab Med 1988;112:1207-13.

25 Fauci AS, Schnittman SM, Poli G, et al. NIH Conference. Immunopathogenetic mechanisms in human immunodeficiency virus (HIV) infection. Ann Intern Med 1991;114: 678-93.

26 Aksamit Aj, Gendelman HE, Orenstein JM, et al. AIDSassociated progressive multifocal leukoencephalopathy (PML): comparison to non-AIDS PML with in situ hybridization and immunohistochemistry. Neurology 1990; 40:1073-8.

27 Orenstein JM, Jannotta F. Human immunodeficiency virus and papovavirus infection in acquired immunodeficiency syndrome: an ultrastructural study of three cases. Human Pathol 1988;19:350-61.

28 Shaw GM, Harper ME, Hahn BH, et al. HTLV-III infection in brains of children and adults with AIDS encephalopathy. Science $1985 ; 227: 177-82$.

29 Genis P, Jett M, Bernton EW, et al. Cytokines and arachidonic produced during human immunodeficiency virus (HIV)-infected macrophage-astroglia interactions: implications for the neuropathogenesis of HIV disease. $\mathcal{F}$ Exp Med 1992;173:1703-18.

30 Hair LS, Nuovo G, Powers JM, et al. Progressive multifocal leukoencephalopathy in patients with human immunodeficiency virus. Hum Pathol 1992;23:663-7.

31 Kuchelmeister K, Gullotta F, Bergmann M, et al. Progressive multifocal leukoencephalopathy (PML) in the acquired immunodeficiency syndrome (AIDS) A neuropathological autopsy study of 21 cases. Pathol Res Pract 1993;189:163-73. 